„Analecta Cracoviensia” 52 (2020), s. 237-246

DOI: https://doi.org/10.15633/acr.4053

Fr. Piotr Kroczek

https://orcid.org/oooo-00o2-6872-2953

The Pontifical University of John Paul II in Krakow, Poland

\title{
The Rights and Duties of Catholic Parish and Evangelical-Augsburg Parish: Ecumenical Perspective ${ }^{1}$.
}

As the history of Christianity indicates, a parish, as a community spontaneously formed by Christ's believers, was the inalienable part of the Primitive Church. ${ }^{2}$ Parish was a basic unit of the Church and had important religious functions to fulfill. ${ }^{3}$ In the parishes, people gathered together for prayers and sharing the bread (Acts 2:42, see Lk 24:35). ${ }^{4}$ In the parishes, they received the sacrament of baptism, became Christians and they "might walk in newness of life" (Rom 6:4). In one sentence - the parish was a center of Christians' religious life. ${ }^{5}$

1 This is a revised and expanded version of the paper that was previosuly published in Romania in "Dionysiana" 12 (2018) no. 1, s. 125-131.

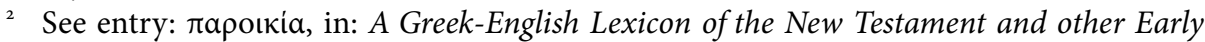
Christian Literature, rev. and ed. F. W. Danker, Chicago-London 2000, p. 779; J. A. Coriden, The Parish in the Catholic Tradition. History, Theology and Canon Law, New York-Mahawah 1997, p. 9.

3 Cf. H. Czembor, Dzieje chrześcijaństwa. Starożytność, Cieszyn 20o1, p. 20.

4 See more in W. Surmiak, "Eamanie chleba” w Nowym Testamencie (Łk 24, 35 i Dz 2, 42), "Śląskie Studia Historyczno-Teologiczne" 36 (2003) z. 2, p. 404-413.

5 Unfortunately, there is a lack of a deep and comprehensive monograph about the history of the christian parish. There are only some small studies about the issue, e.g.: W. Croce, The History of the Parish, in: The Parish - from Theology to Practice, ed. H. Rahner, Westmister 1958, p. 9-22 or R. Kamiński, Parafia wspólnotą i instytucją. Aspekt historyczny, "Roczniki Teologiczno-Kanoniczne" 32 (1985) z. 6, p. 15-35. 
Also, today, a parish seems to be the fundamental institution both for the Catholic Church and the Evangelical Church of the Augsburg Confession in Poland. The institution in question has many dimensions and can be understood as a spiritual community and as an administrative unit of each of the Churches.

The paper aims to give a picture of the similarities between Catholic parish and Evangelical-Augsburg ${ }^{6}$ parish. The similarities are to be presented as a list of the rights and duties of a parish from the perspective of the two Churches in question. Unfortunately, neither Catholic parish nor Evangelical one enjoys the clearly stated list of their rights and duties in the law of the Churches. On the other hand, quite fortunately, the catalog can be construed from the law of the two Churches. The sources of law for the analysis presented in the paper will be the fundamental laws of the two Churches. In the case of the Roman Catholic Church that will be Code of Canon Law from 25 Jan. 1983, promulgated by John Paul II. ' In the case of the Evangelical-Augsburg Church in Poland that will be two documents. First, it is The Essential Inner Law of the Evangelical-Augsburg Church in Poland from 26 Oct. $1996,{ }^{8}$ which contains the essential legal norms for the Church. The second is The Official Policy of the Evangelical-Augsburg Church in Poland from 28 Nov. 1999. ${ }^{9}$ This document, in turn, is a collection of regulations and rules of church service and pastoral care. The legal norms from the given sources can be seen as a source of knowledge of the self-understanding of the individual Church and as a specific, that is legal, description of the reality of the Churches and their parishes.

6 Also in this text: "Evangelical" or "Lutheran."

7 Codex Iuris Canonici auctoritate Ioannis Pauli PP. II promulgates, "Acta Apostolice Sedis" 75 (1983), pars II, p. 1-301; English translation: Code of Canon Law Annotated: Prepared under the Responsibility of the Instituto Martín de Azpilcueta, ed. E. Caparros, M. Thériault, J. Thorn, H. Aubé, 2nd ed., rev. and updated of the 6th Spanish language edition, Montréal 2004 [hereinafter: CIC].

8 Zasadnicze Prawo Wewnętrzne Kościoła Ewangelicko-Augsburskiego w Rzeczpospolitej Polskiej, z dnia 26 października 1996 r. z późn. zm. (tekst ujednolicony z dnia 1 stycznia $2017 \mathrm{r}$.) http://bik.luteranie.pl/files/Prawo/2017-01-o1ZPW-tekstujednolicony.pdf (22.01.2017) [hereinafter: ZPW].

9 Pragmatyka Służbowa Kościoła Ewangelicko-Augsburskiego w Rzeczpospolitej Polskiej z dnia 28 listopada 1999 r. zatwierdzona na 4. Sesji Synodu X Kadencji ze zmianami dokonanymi do 10. Sesji Synodu XIII Kadencji (tekst ujednolicony z dnia 1 stycznia 2017 r.), http://bik.luteranie. pl/files/Prawo/2017-01-o1PragmatykaSubowa-tekstujednolicony.pdf (22.02.2017) [hereinafter: PS]. 
Hopefully, the outcome of the analysis, that is, the list of rights and duties of the parishes, can show the fields for the ecumenical cooperation between the Churches on the parish level.

\section{Existence and continuity of existence}

The key right of a parish, which must be presented as the first one, is the right to existence and the right of the continuity of existence. The two rights logically connected are the foundation for other rights of a parish. The rights have a very strong legal background.

Canon law clearly states it can. 374 par. 1 CIC, that "Each diocese or other particular Church is to be divided into distinct parts or parishes". Almost identical provision one can find in Lutheran law - "Dioceses are created by parishes in the certain area"10 (par. $32 \mathrm{ZPW).} \mathrm{It} \mathrm{means} \mathrm{that} \mathrm{law} \mathrm{orders} \mathrm{evidently:} \mathrm{a} \mathrm{par-}$ ish as an organizational unit of the Church has the right to exist. A Catholic and Evangelical parish is not an optional unit of the Churches. The parishes' existence is of the essence for the Churches.

The right to exist leads to another right of a parish, that is, the right to continuity of existence. The parishes in the Churches in question are not units of the temporary character. The statement is based on the fundamental functions of the parishes. As it was said, from the very beginning raison d'etres of the parishes were common prayers of the Christ's faithful and breaking of the bread. The two activities of the Christian communities are to be held to the end of the world. It creates simultaneously the duty and right of a parish to last forever.

Of course, the two rights are not absolute ones. The existence of a parish depends on the will of the competent authorities of the two Churches. In the case of the Roman Catholic Church that is a diocesan bishop (can. 515 par. 2 CIC) and, at least theoretically, the Pope (can. 332 par. 1 CIC). In the case of the Evangelical-Augsburg Church, the initiative for establishing or suppressing parishes belongs to the Parish Assembly (Zgromadzenie Parafialne), the Diocesan Synod (Synod Diecezjalny), and the Diocesan Council (Rada Diecezjalna) (par. 9 item $\mathrm{f} \mathrm{RD;} \mathrm{par.} 46$ section 1 item $4 \mathrm{ZPW}$ ). The final decision is made by the Consistory (Konsystorz) at the proposal of the listed bodies or on the Consistory's own-initiative (par. 1 section $2 \mathrm{RP}$ ).

It must be added that the Consistory is the supreme administrative authority in the Evangelical Church (par. 66 section 1 ZPW). Slightly differently, the

10 "Diecezje tworzą Parafie znajdujące się na określonym terenie" [translation P. Kroczek]. 
catholic bishop has not only administrative power in his diocese (can. 381 par. 1 CIC) but also, he is a teacher of the faith and his responsibility covers all matters concerning the care of souls (see, e.g., can. 383 par. 1; can. 756 par. 2 $\mathrm{CIC}$ ). The difference means that the decision about the existence of a parish can have its source in the different points of view, and also in the different kinds of arguments.

\section{Autonomy and subjectivity}

The right of a parish to exist as a separate unit in the case of the two Churches in the two systems of law is connected with another right that is the right to autonomy. The right to autonomy is manifested in, e.g., self-governance of the parish, and ownership of goods and administration of them, the possibility of creating customary law for itself.

The autonomy of a parish is not an absolute one. It is limited to the model of the parish that the Church as a whole has and prescribes in its legal regulations and traditions. In another word, regulations create space for the autonomy of the parish. It must be noticed that the right in question is at the same time a duty of the parish. As a consequence, the parish must behave as a separate and autonomous unit and must not give up its rights or pass its right to a different unit of a Church, such as e.g., a diocese.

The realm for autonomy is, as it was said, created by the legal rules. The rules in question have two sources of their existence. The first source is the double dignity of the faithful who create a parish - the human dignity and the dignity of a Christian. The two dignities are in the case of Catholics and Lutherans always connected. It is because only by baptism one is incorporated into the Church of Christ and constituted a person in it (can. 96 CIC; Preliminary statement (Wstępna deklaracja) to ZPW; par. 68 section 3 PS). Apart from human-Christian dignity, the second source of autonomy is the decision of a competent Church legislator.

\section{Unity and orthodoxy}

The ideals and values of unity and orthodoxy play a very important role in Christianity. They echo the call of Jesus: "They may all be one" (Jn 17:21). Christ's calling for unity of His believer's echoes in the doctrine and law of the Christian Churches. Theological teaching about the lack of unity is assessed very negatively. The lack of unity is seen as an outcome of sin. 
Law, of course, follows the theological opinions and contains some provisions that oblige the faithful - individually and collectively (it means also as a parish community) - to stay united with the Church to which they belong (can. 209 par. 1 CIC; par. 247 PS). The obligation in the case of the Catholic Church must exist in many fields like the profession of faith, the sacraments, and ecclesiastical governance (can. 205 CIC). In the Evangelical Church, the ultimate criterion of unity with the Church is the conformity of acts and beliefs with the Gospel and proper distribution of the sacraments (cf. subtitle of point 2.2 PS; par. 56 ZWP).

To abandon unity is in the Catholic Church a canonical crime, and exists in three forms: heresy, apostasy, schism (can. $751 \mathrm{CIC}$ ). The crimes are punished by ex-communication (can. 1364 par. 1 CIC). In the case of the Evangelical Church, the offense in question affects in deprivation of all rights as a member of the Church (par. 247 PS).

The obligation of staying united is enforced by the persons who are in charge of the parishes or the dioceses - mainly pastors or bishops (can. 392 par. 1 and par. 2 CIC; can. 755 par. 1 and par. 2 CIC and analogously par. 16 section 1 PS).

\section{Participation and help}

The unity with the Church causes on the side of a parish the right and duty of participation in other parishes and with the administratively higher structures such as a diocese and the Church. The participation's aim is not only the benefit of the structures in question but also the benefit of a parish itself.

The realization of the right in question the possibility of receiving support from other church structures. The support is described by law. In the case of the Evangelical Church, it refers to possessions, finance, organization, charity, or spirituality (see, e.g. par. 199 PS, and also par. 3 unit $1 \mathrm{RD}^{11}$ ) and in the case of the Roman Catholic Church to pastoral care (can. 374 par. 1 CIC). Of course, the presented enumeration is not exhaustive, but it is an exemplary one. It is because the exercising of the right and duty is regulated by the principle

${ }^{11}$ The Diocesan Regulations of the Evangelical-Augsburg Church in Poland from 18 Feb. 2000 (Regulamin Diecezjalny Kościoła Ewangelicko-Augsburskiego w Rzeczpospolitej Polskiej z dnia 18 lutego 2000 r. z późn. zm.; tekst ujednolicony z dnia 1 lipca 2016 r.), http://bik.luteranie.pl/files/ Prawo/2016-04-27RegulaminDiecezjalny-tekstujednolicony.pdf (22.02.2016). 
of subsidiarity. The principle is contained in the catholic teaching in canon law. ${ }^{12}$ It is also presented in the praxis of the Evangelical Church. The principle orders that the bigger and more potential society brings subsidies to the smaller society or the society of lesser potential. The bigger society can act on its initiative or when social action is requested. The realm of the help is always regulated by the certain legal and factual conditions of a parish and other structures.

\section{Proclamation of the Word of God and celebration of the Eucharist}

The orthodoxy of a parish leads to the most important in theological terms right and duty of a parish, that is, the right and duty of preaching the word of God and celebrating the Eucharist. These two elements are the theological foundations of the existence of a Christian parish.

In canon law, the provisions are clear in this matter. Canon 528 par. 1 states that "The parish priest has the obligation of ensuring that the word of God is proclaimed in its entirety to those living in the parish" and can. 528 par. 2 "The parish priest is to take care that the blessed Eucharist is the center of the parish assembly of the faithful". Evangelical law, in turn, treats the exercise of pastoral care in the parishes mainly as "an obligation for heralding the Word of God ${ }^{13}$ " (par. 42 section $2 \mathrm{RP}^{14}$ ) and celebrating the Sacrament of the Altar that is Eucharist (par. 95 PS; see par. 92 PS).

\section{Missionary nature}

Following the two fundamental rights and duties which were discussed, that is the proclamation of the Word of God and celebration of the Eucharist, and noticing an aspiration of a parish to be a truly orthodox community, the Church creates another duty of a parish, that is, the duty of being a missionary.

${ }_{12}$ See, e.g., J. P. Johnson, The Principle of Subsidiarity in Catholic Social Thought, Atlanta 1994; A. Leys, Ecclesiological Impacts of the Principle of Subsidiarity, Kampen 1995 or R. M. Harrington, The Applicability of the Principle of Subsidiarity According to the Code of Canon Law, Ottawa 1997.

${ }^{13}$ "Zobowiązaniem do zwiastowania Słowa Bożego" [translation P. Kroczek].

${ }_{14}$ The Parochial Regulations from 18 Feb. 2000 (Regulamin Parafialny z dnia 18 lutego 2000 z późn. zm. (tekst ujednolicony z 24 czerwca 2015 r.) http://bik.luteranie.pl/files/Prawo/2015-0624RegulaminParafialnytekstjednolityBIK.pdf (22.02.2017). 
The obligation is expressis verbis enclosed in the words of Christ: "Go into all the world and preach the gospel to all creation" (Mk 16:15; see Mt 28:19-20; Lk 24:46-47; Acts 1:8). Christ's order is read by Catholics and Lutherans the same - the Church has a missionary nature and the parish as well.

It goes back to the statement in canon law that "the work of evangelization is to be considered a fundamental duty of the people of God, all Christ's faithful must be conscious of the responsibility to play their part in missionary activity" (can. 781). In the Catholic Church, every faithful is responsible. In turn, the evangelical law provides very similar missionary provisions (par. 87 PS) but the law pays special attention to the activity of the clergymen in this matter (par. 28 unit 1 PS; par. 66 PS; 36 unit 1 PS; cf. can. 245 par. 1 CIC; can. 256 par. 2 CIC).

In exercising the duty of being a missionary, the parishes are supported by the institutions of the Church. The Catholic parish is supported by The Pontifical Mission Societies, which are under supervision, at the worldwide level, of the Congregation for the Evangelization of Peoples and, at the local level, they depend on the Episcopal Conferences and the bishops of individual churches. In the case of the evangelical Church, the missionary activity of a parish is supported and coordinated by The Centre of Mission and Evangelization of the Evangelical-Augsburg Church (Centrum Misji i Ewangelizacji Kościoła Ewangelicko-Augsburskiego).

\section{Conclusions}

The list of the rights and duties of Catholic and Evangelical-Augsburg parish allows formulating the following conclusions.

First of all, the catalog of the rights and duties of a Catholic parish and Lutheran one is similar or, to some degree, identical. It shows that regardless of the theological and legal differences between the two Churches, a parish theological and legal picture remains almost the same. The two Churches are not very far from each other in this realm.

Secondly, it seems that all the rights and duties of the parish are important not only for the parish itself, but also for the sake of the diocese and the Church. It underlines the importance of the parish for the higher structures in question.

Thirdly, exercising the right and fulfilling duties has not only the juridical dimension but also the theological one. From this perspective, a parish, as a legal entity and as a group of Christ's believers, that follows the legal regulations, creates the space for the Christians to lead successfully the evangelical life. 
Considering all of these, it can be stated that presented above the catalog of rights and duties gives valuable clues for the ecumenical cooperation between the two Churches on the parish level. This relationship can be multidimensional and bring together the faithful of the two Churches on many levels: from purely human to spiritual or religious one. One can even say that there is one model of the Christian parish, which can be seen from a catholic and evangelical perspective.

\section{Abstract}

The Parish is a basic administrative unit of the Catholic Church and the Evangelical Church of the Augsburg Confession in Poland. The research aims to formulate - building on the analysis of the fundamental laws of the Churches in question - a common list of the rights and duties of the parish. One can even say that there is "one Christian parish" which can be seen from a catholic and evangelical perspective.

\section{KEYWORDS}

parish, the Catholic Church, the Evangelical Church of the Augsburg Confession in Poland, rights, and duties

\section{Abstrakt}

Prawa i obowiązki parafii katolickiej i parafii ewangelicko-augsburskiej: perspektywa ekumeniczna

Parafia jest podstawową jednostką administracyjną Kościoła katolickiego i Kościoła Ewangelicko-Augsburskiego w Polsce. Celem artykułu jest sformułowanie w oparciu o analizę podstawowych praw danych Kościołów - wspólnej listy praw i obowiązków parafii. Wniosek z rozważań brzmi następująco: istnieje ,jedna parafia chrześcijańska”, którą można postrzegać w perspektywie katolickiej i ewangelickiej.

\section{SŁOWA KLUCZOWE}

parafia, Kościół katolicki, Kościół Ewangelicko-Augsburski w Polsce, prawa i obowiązki 


\section{BIBLIOGRAPHY}

\section{Sources}

Codex Iuris Canonici auctoritate Ioannis Pauli PP. II promulgatus "Acta Apostolice Sedis" 75 (1983), pars II, p. 1-301; English translation: Code of Canon Law Annotated: Prepared under the Responsibility of the Instituto Martín de Azpilcueta, ed. E. Caparros, M. Thériault, J. Thorn, H. Aubé, $2^{\text {nd }}$ ed., rev. and updated of the $6^{\text {th }}$ Spanish language edition, Montréal 2004.

The Diocesan Regulations of the Evangelical-Augsburg Church in Poland from 18 Feb. 2000 (Regulamin Diecezjalny Kościoła Ewangelicko-Augsburskiego w Rzeczpospolitej Polskiej z dnia 18 lutego 2000 r. z późn. zm.; tekst ujednolicony z dnia 1 lipca 2016 r., http://bik.luteranie.pl/files/Prawo/2016-04-27RegulaminDiecezjalny-tekstujednolicony.pdf (22.02.2016).

The Essential Inner Law of the Evangelical-Augsburg Church in Poland from 26 Oct. 1996 (Zasadnicze Prawo Wewnętrzne Kościoła Ewangelicko-Augsburskiego w Rzeczpospolitej Polskiej, z dnia 26 października 1996 r. z późn. zm. (tekst ujednolicony z dnia 1 stycznia 2017 r.), http://bik.luteranie.pl/files/Prawo/2017-01-o1ZPW-tekstujednolicony.pdf (22.01.2017).

The Parochial Regulations from 18 Feb. 2000 (Regulamin Parafialny $z$ dnia 18 lutego 2000 z późn. zm.; tekst ujednolicony z 24 czerwca 2015 r., http://bik.luteranie.pl/files/ Prawo/2015-06-24RegulaminParafialnytekstjednolityBIK.pdf (22.02.2017).

The Official Policy of the Evangelical-Augsburg Church in Poland from 28 Nov. 1999 (Pragmatyka Stużbowa Kościoła Ewangelicko-Augsburskiego w Rzeczpospolitej Polskiej $z$ dnia 28 listopada 1999 r. zatwierdzona na 4. Sesji Synodu X Kadencji ze zmianami dokonanymi do 1o. Sesji Synodu XIII Kadencji; tekst ujednolicony z dnia 1 stycznia 2017 r., http://bik.luteranie.pl/files/Prawo/2017-01-o1PragmatykaSubowa-tekstujednolicony.pdf (22.02.2017).

\section{Literature}

A Greek-English Lexicon of the New Testament and other Early Christian Literature, rev. and ed. F. W. Danker, Chicago-London 2000.

Coriden J. A., The Parish in the Catholic Tradition. History, Theology and Canon Law, New York-Mahawah 1997.

Croce W., The History of the Parish, in: The Parish - from Theology to Practice, ed. H. Rahner, Westminster 1958, p. 9-22.

Czembor H., Dzieje chrześcijaństwa. Starożytność, Cieszyn 2001. 
Harrington R. M., The Applicability of the Principle of Subsidiarity According to the Code of Canon Law, Ottawa 1997.

Johnson J. P., The Principle of Subsidiarity in Catholic Social Thought, Atlanta 1994.

Kamiński R., Parafia wspólnota i instytucją. Aspekt historyczny, "Roczniki Teologiczno-Kanoniczne" 32 (1985) z. 6, p. 15-35.

Leys A., Ecclesiological Impacts of the Principle of Subsidiarity, Kampen 1995.

Surmiak W., "Eamanie chleba" w Nowym Testamencie ( $Ł k$ 24, 35 i Dz 2, 42), "Śląskie Studia Historyczno-Teologiczne" 36 (2003) z. 2, p. 404-413. 